\title{
An analysis of the impacts of climatic variability and hydrology on the coastal fisheries, Engraulis encrasicolus and Sepia officinalis, of Portugal
}

\author{
Hadayet Ullah ${ }^{1}$, Francisco Leitão ${ }^{2, *}$, Vânia Baptista ${ }^{3}$, Luís Chícharo ${ }^{1}$ \\ ${ }^{1}$ Centre for Marine and Environmental Research (CIMA-UALG), University of Algarve, \\ Campus de Gambelas, 8005-139 Faro, Portugal, e-mail: sumon127@yahoo.com \\ ${ }^{2}$ Centre of Marine Sciences, University of Algarve, Campus de Gambelas, 8005-139 \\ Faro, Portugal, e-mail: fleitao@ualg.pt \\ ${ }^{3}$ Abel Salazar Biomedical Sciences Institute, University of Porto, Rua Jorge Viterbo \\ Ferreira, n² 228, 4050-313 Porto, Portugal, e-mail: vania_bap@hotmail.com
}

\begin{abstract}
The notion that climate change may impact coastal fish production suggests a need to understand how climatic variables may influence fish catches at different time scales. Evidence suggests that the effect of climatic variability and fishing effort on landed catches (as proxy of fish abundance) may vary at the regional scale. This study aims to assess the sensibility of two commercial species with a short life cycle (Engraulis encrasicolus and Sepia officinalis) to climatic and fisheries effects across different regions of the coast of Portugal: northwestern, southwestern and southern Portugal. The effect of environmental explanatory variables, i.e. NAO index, sea surface temperature (SST), upwelling (UPW) index, river discharge, wind magnitude (WmaG), wind direction (Wdir), and fishing variables (fishing effort) on catch rates time series were studied between 1989 and 2009. The sensibility of the species studied to climatic variability differed among regions and were explained by different climatic variables. River discharge had a significant effect on catch rates of the two species, region independently. However, wind driven phenomenon and UPW were the variables that better explained the observed fishing trends across the three regions. Changes in catch rate trends among the studied regions, at a given time, were mostly associated with the reproduction periods of the species. Therefore, regional analyses will significantly contribute to a better understanding of the relationship between climate change and coastal fisheries, aiming to improve integrated coastal zone management.
\end{abstract}

Key words: climate variables, fishing trends, dynamic factor analysis, river discharge, fishing effort, wind driven phenomenon, integrated coastal management. 


\section{Introduction}

The field of coastal ecohydrology is growing and providing new theoretical frameworks and methodological approaches for understanding the complex interactions between biota, such as fisheries resources and climatic factors (e.g. river discharges) at multiple scales. Among several climatic factors, riverine discharge is proved to be an important factor for coastal fisheries (FAO 1995). Application of Ecohydrology concept (Zalewski et al. 1997; Zalewski 2000) for sustainable freshwater fisheries resource management is now well recognized in the scientific community (Zalewski 1998 , 2003). A rapid growth in the research of coastal ecohydrology and hydrology, emphasizing on estuarine and coastal fisheries, has also been observed in the last decade (Chícharo et al. 2001a; Wolanski et al. 2004, 2006; Chícharo et al. 2009; Sohel, Ullah 2012). However, most studies that addressed the relationship between ecohydrology and fisheries dealt mostly with estuarine resources and particularly with river discharge (hydrology) as a single environmental variable (Chícharo et al. 2001a; 2006). In contrast, those works that attempt to link coastal fisheries with climatic factors (multipressures), under the ecohydrological framework, are scarce (Chícharo et al. 2001b).

It is recognized that climate induced variability is a strong driver of changes in fish populations and in fisheries (Roessig et al. 2004; Lehodey et al. 2006). Besides, increasing pressures from over-fishing, habitat destruction and water quality degradation, natural variability of atmospheric and oceanic systems is increasingly affected by climate change, and thus species are forced to physiological or behavioral adaptation to rapidly changing environments (Balston 2009). These changes could be very crucial for instance in small pelagic fish and in species with short life cycles (e.g. cephalopods). Small pelagic fish are contributing up to $50 \%$ of the total landing of marine species (Lluch-Cota et al. 1997) and occupy an important position in the intermediate levels of the food web, connecting the lower and upper trophic levels (Cury et al. 2000). Despite constant progress in understanding the complex processes involved in the variability of pelagic stocks, especially at short and medium time scales, our ability to predict abundance and catches is limited (Fréon et al. 2005). This also limits our capacity to properly manage the fisheries and ensure sustainable exploitation. This remains difficult because small pelagic fishes, such as anchovy, showed important long-term natural fluctuations in their abundance (Lluch-Belda et al. 1989). Furthermore, the impact of changing freshwater flow from rivers into coastal waters throughout the world proved to be a crucial factor for this fisheries (Chícharo et al. 2001a; 2001b; Palomera et al. 2007; Bergeron et al. 2010). Thus, a favorable hydrological and biological conditions is vital for successful recruitment of larvae fish (Wilson et al. 2008) which may consequently affect fishing yields (Hare et al. 2010).

Portugal is likely to face rapid alterations in temperature and precipitation, which are expected to be more accelerated than the global mean alteration rate (IPCC 2001). Studies carried out in the coastal waters of Portugal were basically focused on the influence of certain environmental variables on the recruitment of fish species, on a very short time scale, and their association with suitable nursery grounds. The relationship between a set of long term climatic variables and marine production of commercially important species was not highlighted except by few works (Santos et al. 2001; Borges et al. 2003; Erzini 2005; Santos et al. 2007, 2012). Consequently, there is a lack in terms of understanding potential combined role of climate driven river runoff, sea surface temperature (SST), upwelling (UPW), North Atlantic oscillation (NAO) and wind on the coastal fisheries across the different regions of Portugal (different oceanographic and hydrological regimes). Most studies are limited to specific geographic areas and do not address the issue of climate variability simultaneously across all Portuguese coast (Borges et al. 2003; Erzini 2005; Santos et al. 2007; 2012), that is known to have different climatic regimes (Bettencourt et al. 2004). Since several approaches (such as knowledge-driven approach models, data-driven approach to modeling and hybrid modeling approach) for Ecohydrological modeling are currently available to scientists, the choice of data analyses is made in accordance with the goals and available data sets (Ben-Hamadou et al. 2011). This work used empirical or data-driven model that is based on a statistical fit to data as a way to statistically identify relationships between stressor (climate variables) and response variables (trends of two commercial species, Engraulis encrasicolus and Sepia officinalis).

\section{Materials and methods}

\subsection{Study area}

The sensibility of the two species to climatic variability and fisheries was evaluated across three regions with different oceanographic regimes (Bettencourt et al. 2004): northwestern, southwestern and south Atlantic coast of Portugal (Fig. 1). The northwestern Portuguese coast is characterized by littoral drift currents having a dominant north-south direction, except local deviations due to specific hydrodynamic processes (e.g. near river mouths). The oceanographic conditions along the western 
Iberian Peninsula ecosystems are variable throughout the year, varying from north to south and are more unstable than previously thought (Relvas et al. 2007). This region is characterized by intermittent upwelling events during the winter whereas upwelling events increase in frequency, intensity and length and continue throughout the summer. The northwestern coast is directly influenced by the discharge of three large rivers: Douro (Matosinhos region), Vouga (Aveiro region) and Mondego (Figueira da Foz) respectively. The near shore oceanographic conditions in southwestern coast are very sensitive to the intensity and temporal structure of the upwelling favorable winds, where stronger and more variable winds tend to favor the occurrence of more events of low SST and high chlorophyll concentrations (Oliveira et al. 2008). Two rivers, Tejo and Sado were considered to explore the role of river discharge in southwestern coast. The south coast of Portugal is characterized by mediterranean climate. The Guadiana river is the most important source of freshwater discharge in southern Portugal. The mean monthly Guadiana river flow volumes showed strong variability between and within years, due to the influence of Mediter-

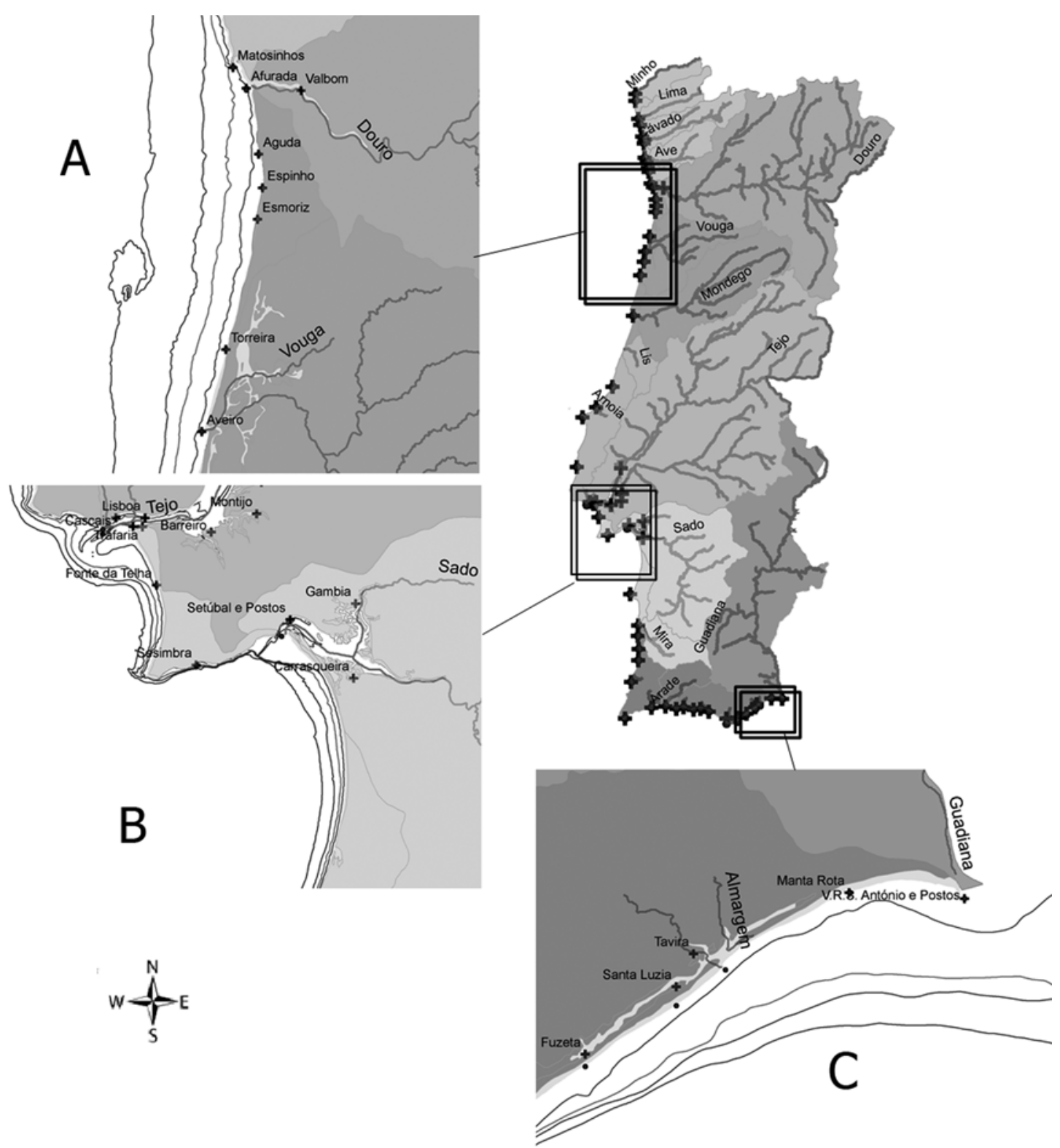

Fig. 1. The location of the three distinct regional coastal water bodies of Portugal A) Northwestern coast B) Southwestern and C) South coast of Portugal. 
ranean climate characteristics. In additional, a large artificial Alqueva dam was built in the Guadiana river in February 2002.

\subsection{Response variables}

Landings and fishing effort data from 1989 to 2009 were obtained from the Direcção Geral das Pescas e da Aquicultura (Directorate General of Fisheries and Aquaculture - DGPA). This includes monthly information on landings and on the effort (number of fishing events per boat). Therefore, annual landings per unit effort (LPUE) were used, as proxy of index of abundance, by dividing yearly total catches by the number of fishing days (events). The response variables considered for this study were two near shore coastal species, Engraulis encrasicolus (European anchovy) and Sepia officinalis (Cuttlefish). The data are from seine nets (pelagic and demersal seine) and multispecies artisanal fisheries. The selection of landing data was based on the relevant landing ports with relation to nearby riverine discharge. The landing data of south Atlantic includes V.R.S António and Tavira main Ports landing (Algarve Leeward, South Portugal) which are under influence of the Guadiana river. The south-western Atlantic includes Sesimbra and Setúbal main Ports, under influence of the rivers Tejo and Sado. The northwestern Atlantic includes data from Matosinhos and Aveiro Ports and the two rivers contribution of freshwater to coastal areas considered were Douro and Vouga, respectively. The main ports account for the landings contribution of secondary ports, within the jurisdiction of the main port.

\subsection{Explanatory variables}

To investigate the effect of climatic variability on the two selected species, different explanatory variables (environmental and fishing ) were selected assuming that they affect species production trends, mainly during the larval stages. Time series of mean monthly values (1989-2009) of sea surface temperature $\left(\mathrm{SST},{ }^{\circ} \mathrm{C}\right)$, upwelling (UPW) index and the North Atlantic Oscillation index (NAO-Win) were collected from the MERSEA (Marine Environment and Security for the European Area) data set (available on http://w3.mersea. eu.org/html/information/data_access.html), Pacific Fisheries Environmental Laboratory - NOAA (data available on http://www.pfeg.noaa.gov) and from Hurrell (1995), data available on http://www.cgd. ucar.edu/ jhurrell/nao.html. The monthly satellite data on easterly $(\mathrm{u})$ and northerly (v) wind components is derived (http://podaac.jpl.nasa.gov,according to Atlas et al. 2011) to estimate the wind magnitude [WMag: SQRT $\left(\mathrm{u}^{2}+\mathrm{v}^{2}\right)$ ] and wind direction
[WDir: degree Arc tangent $\left.{ }^{2}(\mathrm{u}, \mathrm{v})\right]$ and used in the statistical models rather than original wind $u$ and $\mathrm{v}$ data. The geostrophic wind in satellite data are broken into its two horizontal components. River discharge $\left(\mathrm{dm}^{3}\right)$ values for each river were taken from the Portuguese national water web platform, (SNIRH: data available on http://snirh.pt/). All the explanatory variables used for this study were grouped according to season or year. The seasons considered are winter (Win), spring (Spr), summer (Sum) and autumn (Aut) with: (1) winter (January to March); (2) spring (April to June); (3) summer (July to September); and (4) autumn (October to December).

\subsection{Data exploration and modelling}

With the aim of assessing the effect of environmental and fisheries (effort) variables, from different areas, on time series of marine resources, dynamic factor analysis (DFA) was used. Normality of time-series data is not essential for DFA modelling, however, it is beneficial to model performance (Zuur et al. 2003b). Therefore, Lattice and QQ-plots were made to check normality of data. The cross-correlation function that shows the relationship between $Y_{t}$ (response) and $X_{t-k}$ (explanatory variables) can be used to explore whether there is a (linear) relationship between two variables (Zuur et al. 2007, 2009). Therefore, collinearity was also tested. Besides, both response and explanatory variables were standardized (mean subtracted and divided by the standard deviation), ensuring that all the time series data are on the same scale. Thus, each series was centered around zero, had unit variance and was unitless.

Dynamic factor analysis (DFA) is a dimensionreduction multivariate analysis technique that can be used to model non-stationary time series containing missing values (not the present case) to detect underlying common patterns in a set of time series and relationships between these series (so called trends) and explanatory variables (Zuur et al. 2003a, 2003b). DFA applied the same principle as factor analysis, in which the axes are restricted to be latent smoothing functions over time (Zuur et al. 2003a).

To date, almost all the studies that used DFA to investigate the relationship between fisheries trends and explanatory variables were basically focused on analyzing multiple common trends of a certain fishery by using multivariate time series data. This limits the scope to explain the trends for individual species and explanatory variables that influence particular fisheries, instead it explains the potential multiple common trends and relationship of a group of species and combined explanatory variables (Zuur et al. 2003a, 2003b; Zuur, Pierce 2004; Erzini 2005; Erzini et al. 2005; Chen et al. 
2006; Ligas et al. 2010; Santos et al. 2012;). Understanding the potential role of climatic variables on individual species is very important because it can provide adequate information to fisheries managers for a particular species of interest, and thus can play significant role in managing fisheries. In this case, detailed information was available for each species in terms of landings and of the fishing effort. This allowed us to model, independently, the effect of fishing effort over the two species. Therefore, for this study, Brodgar software package (Highland Statistics Ltd, http://www.brodgar.com) was used to fit univariate time series DFA models including combinations with (trends, plus explanatory variables, plus noise) and without explanatory variables (e.g. trend plus noise). The DFA analyses started with the simplest model that is trend plus noise. Then, explanatory variables are tested individually in DFA model in order to address the effect of each explanatory variables on LPUE variability. More than one variable can be combined in DFA analyses in order to test best candidate models. However, the DFA models with more than one explanatory variable required that individually each variable have an effect on landings trends. Moreover, DFA models with combined variables are only tested when time series data belong to the same data period (yearly or similar quarterly data). Therefore, different DFA models (single or combined variables DFA models) showed complementary information and should be contextualized according to data time period. Herein for combined variables we only present the "best" DFA models. The diagonal matrix has advantage with respect to interpretation and diagnostic tools and was used in this study (Zuur et al. 2007). Akaike's information criterion (AIC) was used as a measure of goodness-of-fit and to compare models (Zuur et al. 2003b). Thus, the DFA model with the smallest AIC value was taken to be the optimal model. The estimated parameters with relatively large $t$-values in absolute sense ( $>3$ ) indicate strong relationships (Zuur et al. 2003a).

Knowledge of the species biological characteristics was taken into account prior final modeling analysis. Therefore, lag year 0 and 1 was considered for both E. encrasicolus and S. officinalis. The selection of number of lag years was made on the basis of potential recruitment time of these species into the fisheries, that is age/time of first maturity (Fröese, Pauly 2009). Lag 1 year have provided the best fitted models and results are herein presented.

\section{Results}

The standardized response (LPUE series) and explanatory (excluding fishing effort) variables of the south Atlantic coast of Portugal (Fig. 2), were plotted to visualize the trends overtime. The two studied species showed considerable oscillatory pattern over the studied period with a general decreasing trend except for the S. officinalis at south Atlantic coast of Portugal.

In the southern coast, the landings of E. encrasicolus showed a peak in 1996, followed by a very sharp decline and leveling thereafter except due to another peak in 2004. In contrast, S. officinalis showed a general increasing trend (Fig. 2a), characterized by a moderate landings between 1996 to 2001, followed by a decline and peaking in 2008. Among the explanatory variables, river discharge (Guadiana river, representing south Atlantic) showed high peak after 1995s, followed by a sharp decline and leveling thereafter (Fig. 2b). The mean river discharge for south Portuguese coast was $1992 \times 10^{3} \mathrm{dm}^{3}$ $\left(\mathrm{SD}=2349 \times 10^{3}\right)$ with a minimum of $330 \times 10^{3}$ $\mathrm{dm}^{3}$ and maximum $8458 \times 10^{3} \mathrm{dm}^{3}$ from 1989 to 2009 (Table I). In contrast to river discharge, NAO had minimum values in 1995 , followed by two positive peaks in 2000 and 2007 (Fig. 2b). SST, with an annual mean value of $18.86(\mathrm{SD}=0.3)$, was characterized by two highest peak in 1995 and 2006 (Fig. 2b, Table I). In relation to upwelling index, only once a distinct downwelling regime was observed in 2001, thus upwelling regimes were predominant during the period of study (Fig. 2b). The wind magnitude displayed a large oscillation, however, a slightly increasing trend, over time. Despite the oscillations, two distinct positive peak was observed in 1996 and 2008. The wind direction in winter and autumn blows predominantly from southwest, and in spring and summer predominantly from southeast (Fig. 2c).

In the southwestern Atlantic coast, both E. encrasicolus and $S$. officinalis showed a decreasing trend over time with considerable oscillation (Fig. 3a) though a sharp peak was observed for E. encrasicolus in 1994. Among the explanatory variables, river discharge was characterized by two peaks in 1996 and 2001 (Fig. 3b). The mean river discharge for southwestern Portuguese coast was $9153 \times 10^{3} \mathrm{dm}^{3}\left(\mathrm{SD}=6280 \times 10^{3}\right)$ with a minimum $1729 \times 10^{3}$ and maximum $23023 \times 10^{3} \mathrm{dm}^{3}$ (Table I). A negative phase for SST was observed between 1990 and 1995, reaching to a peak in 1997 followed by another one in 2006 (Fig. 3b). The mean annual SST was recorded as $16.94(\mathrm{SD}=0.37)$ which is lower comparing to south coast (Table I). In relation to yearly upwelling index, downwelling regimes were predominant during the winter and autumn (Table I). Wind magnitude showed considerable oscillation throughout the study period (Fig. 3b). The wind direction in winter, summer and autumn blows predominantly from south while in spring wind direction tends to be blow more from southeast (Fig. 3b). 
In the northwestern coast, the studied species also showed a gradual decline in their landing trends over time (Fig. 4a). The highest peak for E. encrasicolus was observed in 1995 while it was in 1994 for S. officinalis, followed by another moderate positive peak in 2007. Concerning explanatory variables, the mean river discharge for northwestern Portuguese

a

$\rightarrow-$ Engraulis encrasicolus $\rightarrow-$ Sepia officinalis

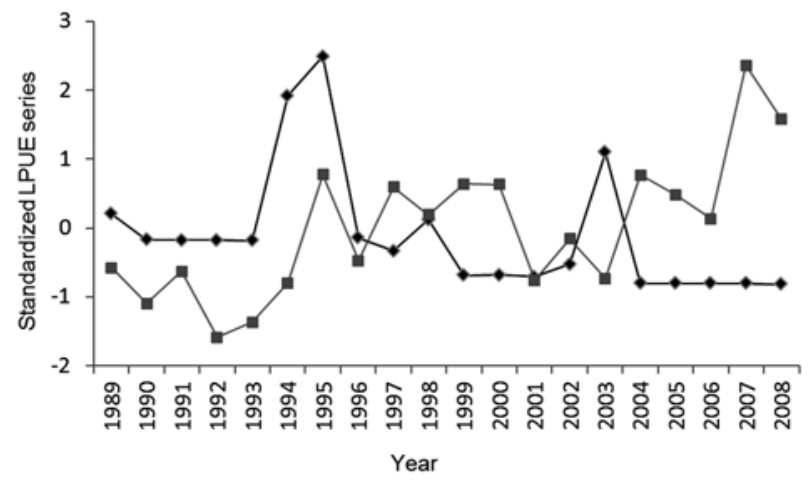

b $\multimap$ Discharge $\rightarrow$ SST $\multimap$ NAO_Winter $\rightarrow$ UPW $\rightarrow$ WmaG
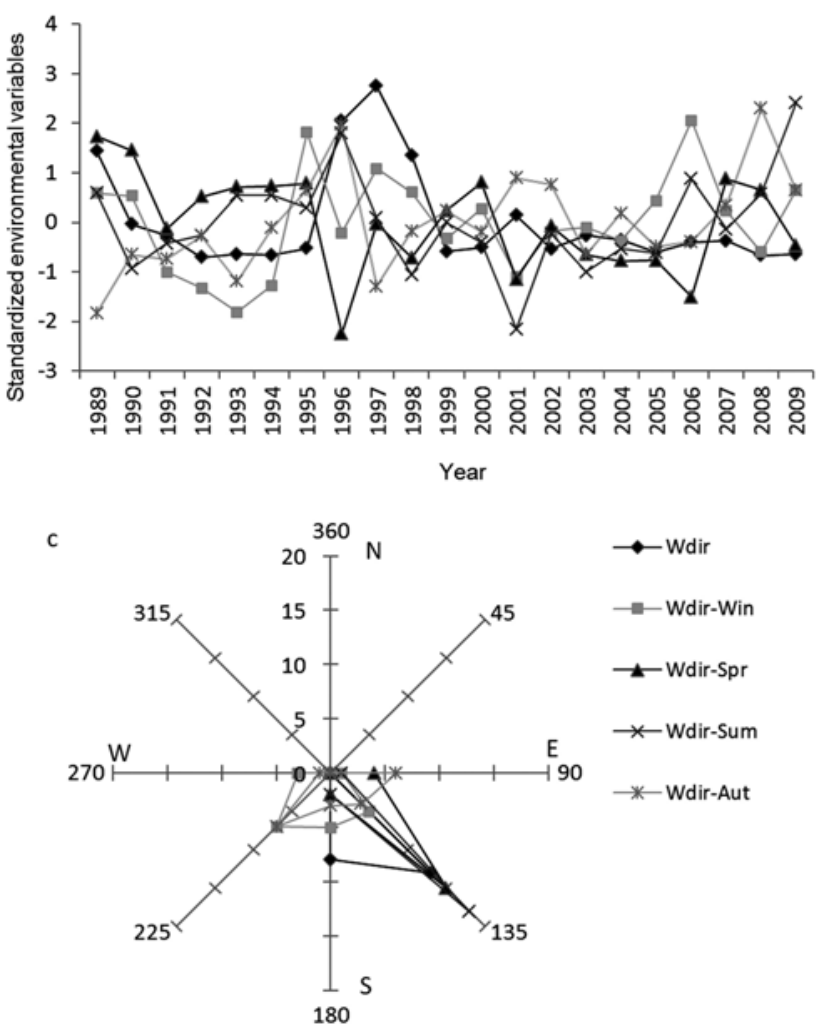

Fig. 2. Standardized mean yearly data for fisheries and environmental variables during the period 1989-2009 for south Atlantic coast of Portugal. (a) Time series plot of response variables (Engraulis encrasicolus and Sepia officinalis), (b) time series plot of environmental variables (Discharge, SST, NAO, UPW, WmaG,), and (c) wind direction (WDir).y coast was $15408 \times 10^{3} \mathrm{dm}^{3}(\mathrm{SD}=7412 \times 103)$ with a minimum of $5458 \times 10^{3}$ and maximum of $36035 \times 10^{3} \mathrm{dm}^{3}$ (Fig. 4b, Table I). Again, a negative phase for SST was observed between 1990 and 1995, reaching to a peak in 1997 and leveling thereafter, except for another small peak in 2006 (Fig. 4b). The lowest mean annual SST, among the three regions, was recorded as $16.11(\mathrm{SD}=0.49)$ in the northwestern coast of Portugal (Table I). Likewise southwestern Atlantic coast, wind magnitude showed considerable oscillation throughout the study period (Fig. 4b). The wind direction in winter and spring blows mostly from southeast while in autumn and summer wind direction tends to be from south (Fig. 4c).

Close inspection of the fitted curves of the studied model species revealed that all the LPUE series were fitted reasonably (Fig. 5). Among the regions, the best fit DFA model with two environmental variables for E. encrasicolus was the one that include SST-Win and WmaG-Win at the south Atlantic coast of Portugal. For S. officinalis, the best fit DFA model was the one that include Discharge-Spr and SST-Spr at the northwestern Atlantic coast of Portugal. An interesting pattern was observed for S. officinalis in the south coast where this species showed a gradual increase in their LPUE, however, a considerable oscillatory pattern was observed at southwestern and northwestern region.

With one explanatory variable, the best fit DFA model for E. encrasicolus was the one that include WmaG-Aut at the coast of south Atlantic (Table II) whereas it was UPW-Spr at southwestern Atlantic and Wdir at northwestern Atlantic coast of Portugal. The seasonal wind direction (winter, spring and autumn) was also related with changes in E. encrasicolus catches. Significant opposite relationship was found between $E$. encrasicolus and seasonal river discharges (spring and summer) at the northwest coast and in the south coast of Portugal while no significant relationship was observed at Southwestern coast.

S. officinalis showed significant positive relationship with river discharge both in spring and summer at northwest coast of Portugal. In contrast, significant negative relationship was observed between $S$. officinalis and river discharge in summer at south coast while no relationship was observed at Southwestern coast. The best model for S. officinalis was that with NAO-Win index 


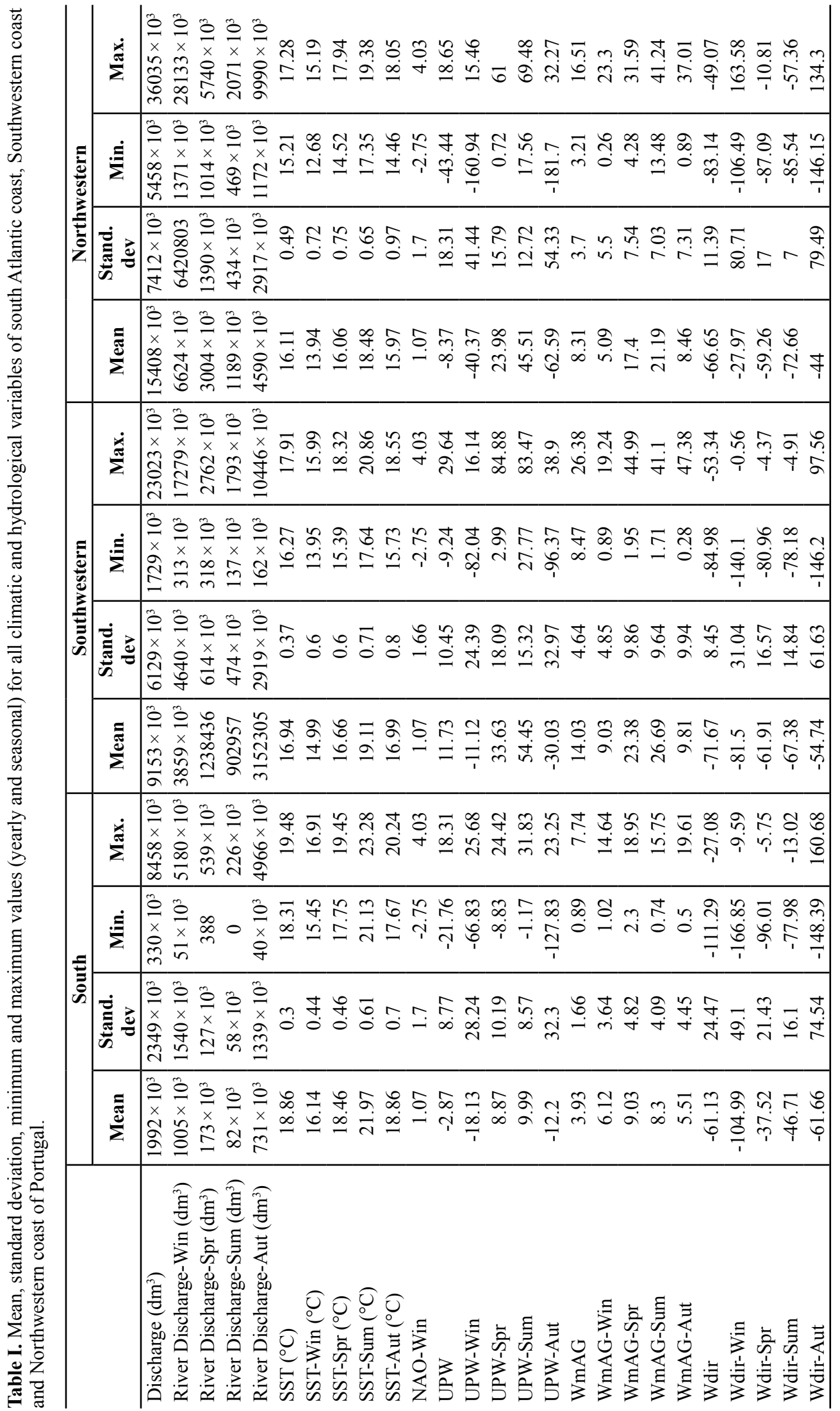


at south Portuguese coast, while it was with UPW at southwestern and with River discharge-Spr at northwestern Portuguese coast.

\section{Discussion}

Coastal ecohydrology approach stand with the promise in successful management of estuar-
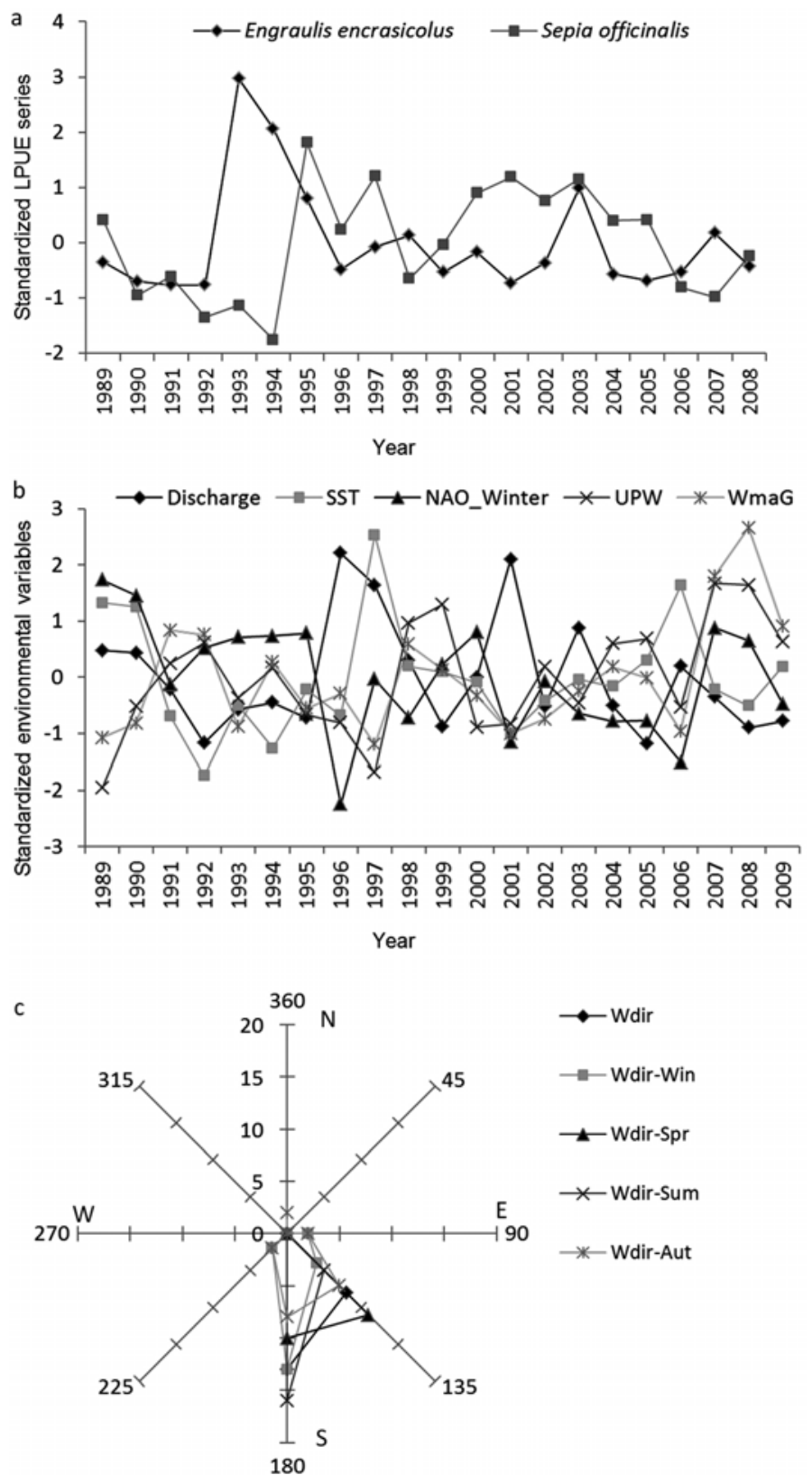

Fig. 3. Standardized mean yearly data for fisheries and environmental variables during the period 1989-2009 for southwestern Atlantic coast of Portugal. (a) Time series plot of response variables (Engraulis encrasicolus and Sepia officinalis), (b) time series plot of environmental variables (Discharge, SST, NAO, UPW, WmaG,), and (c) wind direction (WDir). ies and coastal resources. Application of coastal ecohydrology approaches and solutions proved to be successful to enhance carrying capacity and restore functioning of estuaries and coastal areas impacted by dams and climatic changes (Chícharo et al. 2009, 2010). Addressing this, the present study investigated the sensibility of two coastal species against long term climatic variability and flow regime. Evidences suggest that the environmental variability is largely responsible for the oscillations in the general trends of important commercial coastal fisheries of the world, at the intra- as well as the inter-annual level and among geographical regions (Mann, Lazier 1991; Lluch-Cota et al. 1997; Myers, Worm 2003; Checkley et al. 2009). The results of the present study showed that the relationship between climatic and hydrological variables and species catches rates (time lag 1 year) considerably varies among different geographical distribution ranges. This is not surprising since different oceanographic and hydrological conditions are found in each area (Table I).

However, in general, $\mathrm{WmaG}$ and Wdir were the explanatory variables which better explained variations in fishing trends, particularly for E. encrasicolus, in the south and northwestern Atlantic coasts, followed by river discharge, while UPW seems to be more important for the fisheries of the southwestern Atlantic coast. Since, small pelagic species are close to the base of the food web, they are able to accumulate biomass as well as to grow fast into very large populations. At the same time, they are more sensitive to any change occurring in their environment (Alheit 2002). Therefore the significant difference observed for different species in the present study, in relation to explanatory variables at temporal and spatial scale, is quite understandable. These results are congruent with some of the previous observations on coastal and marine species (Csirke, Sharp 1984; Beukema et al. 1990; Kawasaki et al. 1991). These authors indicated that even relatively minor changes of climate are likely to result in major and drastic changes in the abundance of some coastal and marine species. Moreover, catch rate 
and climate relationships can be often region and species specific because of the difference in bioregions (Pease 1999), genetic variation, physiological adaptation of the species (Colosimo et al. 2003), life history and complex interactions between local environmental variables such as salinity, temperature, turbidity, type of substratum and vegetation (Blaber 1997).

E. encrasicolus usually spawn in spring and to some extent summer in the coast of Portugal (Ré et al. 1983; Motos et al. 1996; Borja et al. 2008). The specific mechanisms linking climate variability and small pelagic regimes are not fully understood. However, the usual assumption that explains the variability in fish stock is that the differential survival of the egg-to-larvae stage determines the amount of recruitment, and thus abundance in the following years (Lluch-Cota et al. 1997). Therefore, the significant negative relationship of E. encrasicolus with WmaG-Aut, implies that the fish larvae that are spawned during spring or summer, suffer higher mortality due to the unfavorable wind condition in the southern coast of Portugal. Wind magnitude may affects larvae swimming behavior during pelagic stages, and the period larvae remain in pelagic stage before settlement, and consequently long term fishing recruitment (Chícharo et al. 2001a; 2001b). Moreover, these young larvae may be transported further offshore or locations where food is limiting or with other adverse environmental conditions. This assumption is well supported by the findings of Catalan et al. (2006) and Ruiz et al. (2006). These authors demonstrated that larval survival is controlled by the intensity of easterlies winds, due to its potential to advect the larvae away from favorable conditions in the shelf zone.

In contrast, significant positive relation was found between E. encrasicolus and mean wind direction in southwestern and northwestern coast as well as with seasonal values except in summer at the northwestern coast. Thus, southeasterly wind that blows during the spring, that is the peak spawning season of
E. encrasicolus, seems to be beneficial for larval survival, and thus for a better recruitment. Therefore, such results might also indicated that larval transport can occur across the coastal area, that is from southeast to northwest. In fact hydrological models of the Portuguese coast showed a circulation water pattern from north to south (Relvas, Barton 2002), thus potentially affecting larvae transport. Though
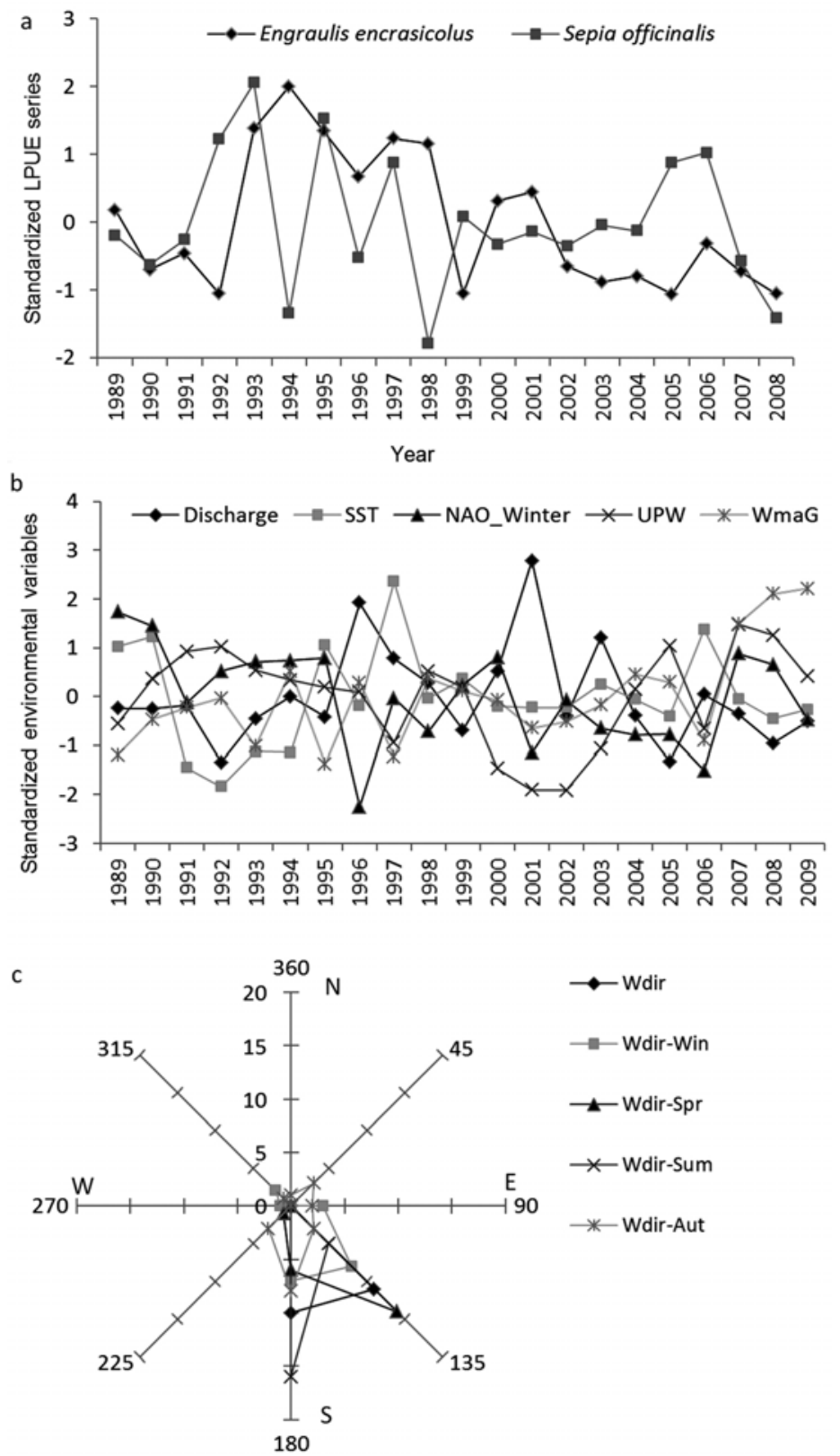

Fig. 4. Standardized mean yearly data for fisheries and environmental variables during the period 1989-2009 for northwestern Atlantic coast of Portugal. (a) Time series plot of response variables (Engraulis encrasicolus and Sepia officinalis), (b) time series plot of environmental variables (Discharge, SST, NAO, UPW, WmaG,), and (c) wind direction (WDir). 
the influence of southeasterly in southwestern and northwestern coasts proved beneficial, southwesterly (winter and autumn) and southeasterly (spring) wind directions do not showed positive influence on E. encrasicolus fishery in the south coast of Portugal. In the south coast, strong southeasterly wind may blow the larvae further west, out of the suitable spawning and nursing ground that is already threatened due to the reduced freshwater flow. In fact upwelling, that is highly influenced by wind direction, seems to be detrimental for this population in the southwestern coast. Santos et al. (2001) reported that upwelling events observed off this coast of Portugal during winter months was detrimental for sardine, another species of clupeids, while spawning season of the fish species occur. The similar situation might occur in case of E. encrasicolus because favorable wind direction (north winds in north regions) is the main force driven upwelling events in shallow coastal areas, namely at shallow coastal areas ( $\sim 40 \mathrm{~m}$ depth).

River discharge also plays a vital role in explaining trends variability of $E$. encrasicolus, mostly on south coast that presented lower yearly and seasonal discharge than in northwestern coast, the latter area characterized by the higher riverine discharge in the coast of Portugal. The negative relationship with seasonal river discharge in south coast and a positive relationship in southwestern and northwestern coast implies that this species is very sensitive in response to any disturbance in natural flow regime. The natural inflow in southern coast, mostly Guadiana estuary, is suffering from considerable negative impact from upstream activities, and an altered flow regime is observed over the years. The impacts become prominent after finishing the construction of the Alqueva dam in the Guadiana river basin in February 2002. Consequently, immediate changes in the frequency and flood cycle, salinity level, seston and organic matter content in the estuarine and coastal system of Guadiana river were observed (Chícharo et al. 2006; Chícharo et al. 2009). Noteworthy the higher chlorophyll concentrations in the Guadiana estuarine and coastal system were associated with higher freshwater input during 2001, however, a weak productive year was observed during the low inflow year of 2002 (Chícharo et al. 2006). E. encrasicolus, that spawn between spring and summer, a period according DFA when river discharge affect negatively LPUE trends time lag 1 year, is highly sensitive to flow regime fluctuations. In fact, Chícharo et al. (2001) argued that changes in river inflow might affect the spawning behavior of $E$. encrasicolus adults and also the migration patterns of larvae (namely larvae survivor capacity), subsequently effecting catches of fisheries in the lower part of the river and adjacent coastal areas. Moreover, these authors also concluded that an increase in freshwater inflow during the spring months will disturb the larvae migration patterns, that is crucial for the survival of larvae in the estu-

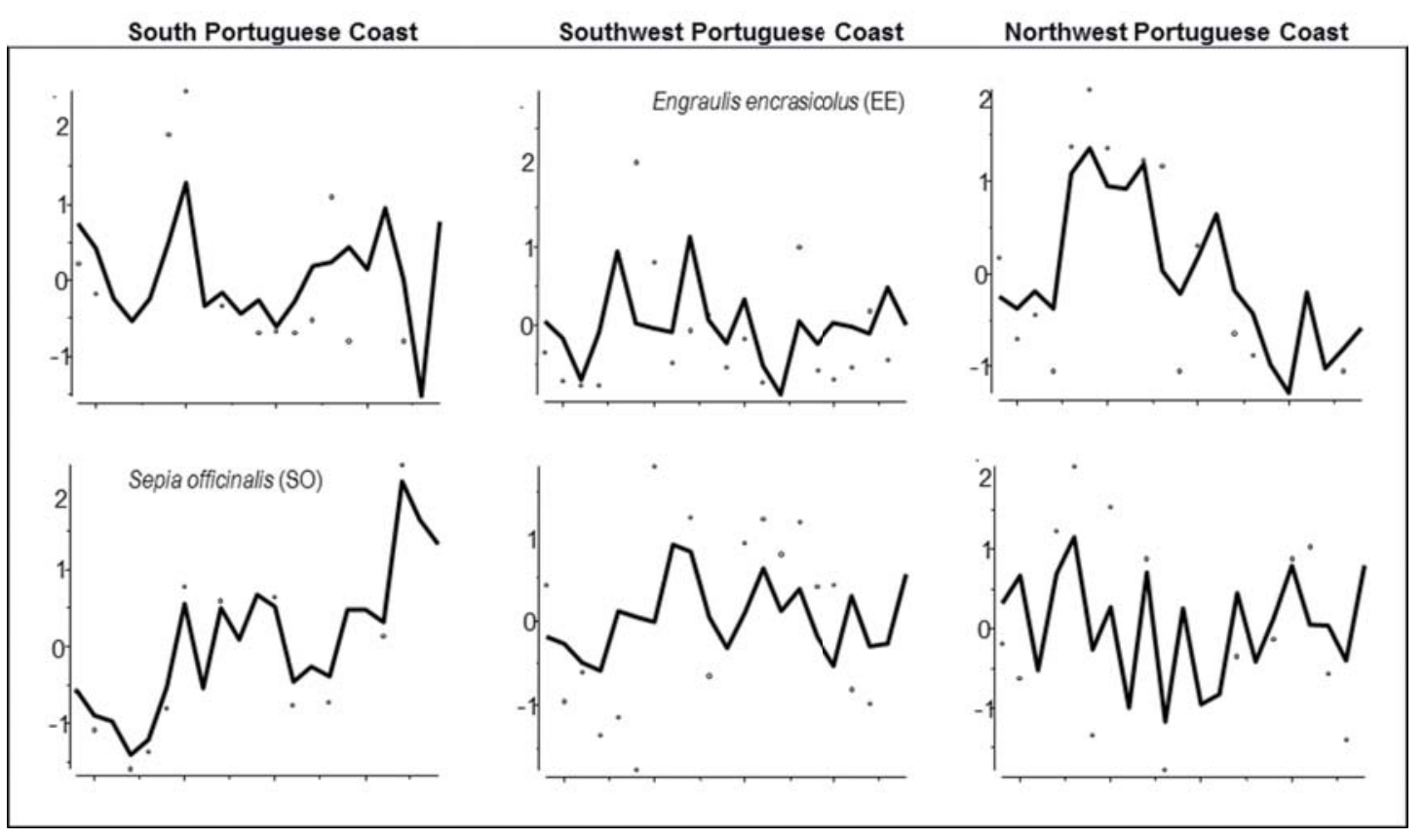

Fig. 5. Observed (filled circle) and fitted (lines) LPUE for the DFA models with trend and the best two environmental variables for individual model species; south coast: $\mathrm{EE}=\mathrm{SST}-\mathrm{Win}+\mathrm{WmaG}-\mathrm{Win}(45.921), \mathrm{SO}=\mathrm{UPW}-\mathrm{Win}+\mathrm{NAO}-\mathrm{Win}$ (50.239), southwestern coast: $\mathrm{EE}=\mathrm{UPW}-\mathrm{Spr}+\mathrm{WmaG}-\mathrm{Spr}$ (60.732), SO = Discharge + UPW (58.412), northwestern coast: $\mathrm{EE}=$ Discharge + Wdir (52.383), SO $=$ Discharge $-\mathrm{Spr}+\mathrm{SST}-\mathrm{Spr}$ (50.091). 
ary. The impacts of reduced freshwater inflow on E. encrasicolus larvae and eggs were also reported by several authors (Chícharo et al. 2006; Morais 2007; Morais et al. 2009). In contrast, high river inflow is found to be associated with an increased input of nutrients (Chícharo et al. 2001a; 2001b) and spreading of turbidity plumes (Chícharo et al. 2006) that assist the orientation of coastal adult fishes to find suitable spawning and nursery areas in estuarine environments. This is particularly important because survival of E. encrasicolus larvae is highly dependent on suitable spawning and nursery areas (Bonanno et al. 2013). E. encrasicolus catches rates in southwestern and northwestern coast were not negative related with higher riverine discharge, as compared to south coast. Therefore, we believe that river discharge in northwestern Portuguese coast during the spawning seasons of $E$. encrasicolus meets the requirements for successful spawning and thus recruitment which is certainly not the case in south coast of Portugal.

Sobrino et al. (2002) demonstrated that cuttlefish abundance is not correlated with any of the variables herein studied (river discharge, rain and SST). Other cephalopod, Octopus, seems to be very much affected by the environment (SST), particularly in early-life stages. However, in the present study, S. officinalis presented a significant positive relationship with NAO-Win index at south coast, while significant negative relation with UPW and River discharge-Spr at southwestern and northwestern coast, respectively. There is no study about the relationship between NAO index and $S$. officinalis, however, the abundance of small L. forbesi, an important squid fishery resource in the north Atlantic, was significantly related to the NAO-Win

Table II. Akaike's information criterion (AIC) values for DFA models (time lag 1 year) for south Atlantic coast, southwestern coast and northwestern coast of Portugal (significant values in each model are in bold). The - sign indicates estimated $t$-values for explanatory variables with a negative relationship, while + indicates a positive relationship; -- or ++ indicates t-values larger than 3 , indicating a strong relationship.

\begin{tabular}{|c|c|c|c|c|c|c|}
\hline \multirow{2}{*}{ Explanatory var. } & \multicolumn{2}{|c|}{ South Atlantic coast } & \multicolumn{2}{|c|}{ Southwestern coast } & \multicolumn{2}{|c|}{ Northwestern coast } \\
\hline & $\mathbf{E E}$ & SO & $\mathbf{E E}$ & SO & EE & SO \\
\hline 1 trend + noise & 50.373 & 55.06 & 61.732 & 61.732 & 57.69 & 61.732 \\
\hline \multicolumn{7}{|c|}{1 trend + expl. var $(\mathrm{s})+$ noise } \\
\hline Discharge & 52.094 & 57.035 & 63.406 & $61.063+$ & $56.506+$ & 62.938 \\
\hline River Discharge-Win & 52.21 & 56.389 & 63.161 & 62.222 & 58.639 & 62.703 \\
\hline River Discharge-Spr & 49.822- & 56.481 & 63.112 & 63.329 & $\mathbf{5 7 . 0 7 3 +}$ & $54.498-$ \\
\hline River Discharge-Sum & 47.896- & $54.292+$ & 63.196 & 63.73 & $57.226+$ & 59.14- \\
\hline River Discharge-Aut & 52.366 & 56.388 & 63.643 & 62.141 & 58.881 & $61.237+$ \\
\hline SST & 51.243 & $54.605+$ & 63.04 & 62.86 & 58.215 & 61.735 \\
\hline SST-Win & 50.554 & $52.592+$ & 63.49 & 63.133 & 58.731 & 60.398-- \\
\hline SST-Spr & 52.242 & 56.963 & 63.243 & 62.341 & 58.835 & 62.033 \\
\hline SST-Sum & 52.149 & 57.047 & $60.55-$ & 64.088 & 57.273- & 63.725 \\
\hline SST-Aut & 48.157+ & 54.549+ & 63.697 & 63.259 & 58.416 & 61.911 \\
\hline NAO-Win & 51.977 & $50.545+$ & 62.382 & 62.876 & 59.69 & 63.732 \\
\hline UPW & 49.48 & 56.831 & 63.582 & 56.709- & 57.033- & 62.424 \\
\hline UPW-Win & 52.043 & 57.052 & 63.397 & 62.647 & 59.373 & 62.778 \\
\hline UPW-Spr & 48.801- & 57.029 & $60.225-$ & 63.467 & 56.937- & 63.629 \\
\hline UPW-Sum & 52.353 & 56.527 & 63.667 & 61.47- & $56.598+$ & 62.91 \\
\hline UPW-Aut & 51.772 & 56.748 & 63.731 & 58.383- & 58.573 & 63.23 \\
\hline WmAG & 51.975 & 57.004 & 62.127 & 61.533- & 58.274 & $53.824-$ \\
\hline WmAG-Win & 50.208- & 56.525 & 62.928 & 63.532 & $\mathbf{5 7 . 2 4 5 +}$ & 62.214 \\
\hline WmAG-Spr & 50.297- & 56.564 & 61.545- & 63.568 & $56.506-$ & 62.039 \\
\hline WmAG-Sum & 51.825 & 56.707 & 62.809 & 62.533 & $56.304+$ & 63.392 \\
\hline WmAG-Aut & 47.774- & $54.683+$ & 63.164 & 63.142 & 59.617 & 58.906- \\
\hline Wdir & 52.334 & 56.429 & $60.763+$ & $60.553+$ & $53.933++$ & 61.866 \\
\hline Wdir-Win & $50.208-$ & 56.33 & 62.547 & 62.192 & 58.078 & 63.019 \\
\hline Wdir-Spr & 50.297- & 57.026 & $61.537+$ & 63.603 & 57.996 & 63.433 \\
\hline Wdir-Sum & 51.825 & 56.53 & 63.715 & 63.379 & 54.91- & 63.683 \\
\hline Wdir-Aut & 47.775- & 57.056 & 62.415 & $57.863+$ & 57.524+ & 62.182 \\
\hline Fishing effort & 51.775 & 55.793 & 62.558 & 62.194 & 59.471 & 63.719 \\
\hline
\end{tabular}


index in Scottish waters (Chen et al. 2006). The spatial distribution of SST data displayed that in the south coast, yearly and seasonal SST values were always higher than southwestern and northwestern coast of Portugal. The significant positive influence of SST on the catch of $S$. officinalis reveals that higher SST favors this species in the south coast of Portugal. This might be due to the fact that most of the cuttlefish prefer to hatch during summer $\left(>20^{\circ} \mathrm{C}\right)$ and higher temperature tends to favor faster embryonic development (Domingues 2006) and somatic growth (Bettencourt 2000). The positive relationship between SST and local abundance of cuttlefish was also reported by Wang et al. (2003) and Guerra (2006). The significant negative relation between S. officinalis and UPW might be due to the fact that the cold upwelling waters lower the temperature of surrounding environment. Thus, it prevents successful spawning, recruitment and fast larval growth for this species in the southwestern coast. This is coinciding with the significant negative $t$-value that was obtained for this species in its peak spawning season that is in spring. Besides $S$. officinalis apparently seems to be negatively affected by higher riverine discharge that is observed during spring and summer in the northwestern coast, when reproduction activity is higher (Jorge, Sobral 2004). In contrast, the species was significantly positively related with remarkably low river discharge (during summer) in the south Portuguese coast. Thus we speculate that this species might be large sensitive to higher river discharge namely during spawning seasons, based on results herein recorded. This is supported by the findings of Jorge and Sobral (2004) who reported a negative relationship between strong precipitation and cuttlefish abundance in the Ría de Aveiro while SST and water transparency favors cuttlefish abundance. However, Sobrino et al. (2002) did not find any correlation between cuttlefish and river discharges at SW coast of Spain.

Wind driven phenomenon such as $\mathrm{WmaG}$ and Wdir proved to be very important environmental variables effecting studied coastal species. The two latter variables affect upwelling and also changes in water temperature. Wind, wave and current interactions largely control hydrodynamics (the boundary fluxes, momentum and energy exchange between the atmosphere and the ocean, and within the water column) in the ocean environment (Zhang et al. 2009). In fact, hydrodynamics is considered as one of the key factors for the successful recruitment of marine fishes (Wilson et al. 2008); which largely controls and influence current speeds, magnitude and direction, thus play the potential role in larval dispersion between offshore and onshore and to some extent inside the estuarine zone (Guisande $e t$ al. 2001; Landaeta, Castro 2002). Most of the cases, wind induced phenomenon was found to have a negative impact on the studied species during their spawning and post-spawning period in the southern coast while the opposite was observed at northwestern coast. Borges et al. (2003) demonstrated a long-term changes in alongshore winds off the coast of Portugal in winter months and opined that northerly winds that favor upwelling led to unfavorable conditions for egg and larval survival of small pelagic. These authors also noted that recruitment is forced to a lower level when the frequency and intensity of northerly wind exceeds a certain limit in winter. This indicate that although wind intensities may favor coastal fisheries through nutrient rich cooler water by upwelling event, intensification of wind induced phenomenon during spawning event and post-spawning period may also impose negative effect on the recruitment of these coastal pelagic species. Furthermore, the presence of favorable density independent physical attributes such as wind magnitude and direction between spawning and the successful arrival in the nurseries, has been proved crucial for successful recruitment, because this time is subject to higher mortality rates (Houde 1987). In the southwestern coast, potential influence of upwelling on the coastal fisheries is well described by Santos et al. (2001) and Borges et al. (2003) which is also observed in the present study.

DFA models with two explanatory variables also provided useful information. In the southwestern coast, DFA models with two explanatory variables provide higher AIC values (such as SSTSum and UPW-Spr for E. encrasicolus and UPW, UPW-Aut and Wdir-Aut for S. officinalis) than the model with one explanatory variables, although both significant. The results of the three best DFA models, at different regions, for E. encrasicolus pointed out wind driven variables (WmaG, UPW, Wdir) as major factors, followed by discharge and SST, that better explain the species catch rate trends. For S. officinalis, discharge and UPW appears to be dominating variables in the DFA models with two variables. The relative importance of wind driven variables and river discharge in DFA models, with two variables (synchronic effects), in fact reflects the findings of the DFA models with one explanatory variables. Specifically, the results of the DFA models showed that variables that explain species trends varied considerably in different geographical regions. Thus, it is not easy to explain the variability of catch rates with multiple combined variables in the estuarine and coastal ecosystem. Nevertheless, the importance of river discharge is only prominent in the northwestern Portuguese coast, in DFA models with two variables. Point to note that distinguishing changes due to freshwater flow from other environmental factors that are extremely variable in estuarine and coastal systems is more often difficult (Costa et al. 2007). Herein, single and combined variables 
DFA models should be considered complementary for explain fisheries changes. Moreover, we like to address the DFA models with one explanatory variables also as the basis for further investigation namely as far as regional coastal management measures concerns.

Fishing effort did not show any significant influence on fish species trends. Nevertheless, detail information on effort was used. The commercial valuable species $E$. encrasiolus is not targeted directly by any métier (it is caught during sardine pelagic seine) and $S$. officinalis is mostly caught in multispecies artisanal fisheries. Therefore the results of this study reveals that climatic variability might superimpose the effects of anthropogenic (effort) variables, at least for the species and regions analyzed.

\section{Conclusion}

Results of this study suggests that river discharge is an important variable that negatively affects landings in the south while the effect was positive in northwestern coast of Portugal, the regions with lower and higher discharge regimes respectively. These effects were predominantly associated with the influence on the corresponding spawning seasons of the studied species. In general, river discharge proved to be important for the E. encrasicolus at the south Atlantic and at northwestern Atlantic. However, wind driven variables were the variables that better explain variations in landings of both species particularly in seasonal periods related to reproduction events. The two species herein studied, anchovy and cuttlefish, have shown wide variability in their LPUE trends among the studied regions due to different explanatory variables. This is an important indication for the Portuguese fisheries management since climate change will more likely influence the local and regional variables in the coming decades. Furthermore, continuous anthropogenic disturbance on the natural environment such as reducing freshwater flow will probably make the situation worst. Therefore, evidence of a causal link between climatic variables and coastal fisheries off the coast of Portugal may provide fisheries managers with the opportunity to increase local and regional catch predictions and so to improve the capacity towards better and sustainable harvesting of a particular fisheries resource.

\section{Acknowledgements}

This study had the support from the European Union through an Erasmus Mundus Master scholarship program in Ecohydrology that first author gratefully acknowledged. We would also like to express our thanks to the DGPA bureau, namely
Carlos Moura for providing fisheries data. F. Leitão (SFRH/BPD/63935/2009) is supported by a Post-Doc grant from the Fundacão para a Ciência e Tecnologia. We would like to thank to anonymous reviewers for their valuable comments that contributed to improve the manuscript.

\section{References}

Alheit, S. 2002. Impact of climate variability on small pelagic fish stock -a comparative view. Invest. mar. 30(1), 175-175.

Atlas, R., Hoffman, R.N., Ardizzone, J., Leidner, S.M., Jusem, J.C., Smith, D.K., Gombos, D. 2011. A crosscalibrated, multiplatform ocean surface wind velocity product for meteorological and oceanographic applications. Bull. American Meteorol. Soc. 92, 157-174.

Balston, J. 2009. An analysis of the impacts of long-term climate variability on the commercial barramundi (Lates calcarifer) fishery of north-east Queensland, Australia. Fish. Res. 99, 83-89.

Ben-Hamadou, R., Atanasova, N., Wolanski, E. 2011. Ecohydrology modeling: tools for management. Ecohydrology and Restoration. Treatise on Estuarine and Coastal Science 10 (Ecohydrology and Restoration), pp. 301-328.

Bergeron, J., Delmas, D., Koueta, N. 2010. Do river discharge rates drive the overall functioning of the pelagic ecosystem over the continental shelf of the Bay of Biscay (NE Atlantic)? A comparison of two contrasting years with special reference to anchovy (Engraulis encrasicolus L.) nutritional state. J. Oceangr. 66(5), 621-631.

Bettencourt, A., Bricker, S.B., Ferreira, J.G., Franco, A., Marques, J.C., Melo, J.J., Nobre, A., Ramos, L., Reis, C.S., Salas, F., Silva, M.C., Simas, T., Wolff, W. 2004. Typology and reference conditions for Portuguese transitional and coastal waters, development of guidelines for the application of the European Union Water Framework Directive. Lisbon: Instituto da Agua (INAG) - Institute of Marine Science (IMAR). http://www.ecowin.org/TICOR/

Bettencourt, V. 2000. Idade e crescimento do choco, Sepia officinalis L. Ph D Thesis, Univ Algave, Portugal, $196 \mathrm{p}$.

Beukema, J.L., Wolf, W.J., Brouns, J.J.W.M. 1990. Expected effects of climatic change on marine coastal ecosystem. Developments in Hydrobiology 37, Kluwer Academic Publishers., Dordrecht, Netherlands.

Blaber, S.J.M. 1997. Fish and Fisheries of Tropical Estuaries. Chapman \& Hall, London.

Bonanno, A., Zgozi, S., Cuttitta, A., El Turki, A., Nieri, A., Ghmati, H., Basilone, G., Aronica, S., Hamza, M., Barra, M., Genovese, S., Falco, F., Knittweis, L., Mifsud, R., Patti, B., Bahri, T., Giacalone, G., Fontana, I., Tranchida, G., Mazzola, S. 2013. Influence of environmental variability on anchovy early life stages (Engraulis encrasicolus) in two different areas of the Central Mediterranean Sea. Hydrobiol. 701(1), 273-287.

Borges, M.F., Santos, A.M.P., Crato, N., Mendes, H., Mota, B. 2003. Sardine regime shifts off Portugal: a 
time series analysis of catches and wind conditions. Sci. mar. 67 (Suppl.1), 235-244.

Borja, A., Fontán, A., Sáenz, J.O.N., Valencia, V. 2008. Climate, oceanography, and recruitment: the case of the Bay of Biscay anchovy (Engraulis encrasicolus). Fish. Oceanogr. 17(6), 477-493.

Catalan, I.A., Rubin, J.P., Navarro, G., Prieto, L. 2006. Larval fish distribution in two different hydrographic situations in the Gulf of Cádiz. Deep-Sea Res. 53, 1377-1390.

Checkley, D.M., Alheit, J., Oozeki,Y., Roy, C. 2009. Climate Change and Small Pelagic Fish. Cambridge University Press.

Chen, C.S., Pierce, G.J., Wang, J., Robin, J.P., Poulard, J.C., Pereira, J., Zuur, A.F., Boyle, P., Bailey, N., Beare, D., Jereb, P., Ragonese, S., Mannini, A., Orsi-Relini, L. 2006. The apparent disappearance of Loligo forbesi from the south of its range in the 1990s: trends in Loligo spp. abundance in the northeast Atlantic and possible environmental influences. Fish. Res. 78, 44-54.

Chícharo, L., Chícharo, M.A., Esteves, E., Andrade, P., Morais, P. 2001a. Effects of alterations in freshwater supply on the abundance and distribution of Engraulis encrasicolus in the Guadiana estuary and adjacent coastal areas of south Portugal. Ecohydrol. Hydrobiol. 1(3), 341-345.

Chícharo, M.A., Chícharo, L., Galvão, H., Barbosa, A., Marques, M.H., Andrade, J.P., Esteves, E., Miguel, C., Gouveia, I. 2001b. Status of the Guadiana estuary (South Portugal) during 1996-1998: an ecohydrological approach. Aquat. Ecosyst. Health. 4, 73-90.

Chícharo, M.A., Chícharo, L., Morais, P. 2006. Inter-annual differences of ichthyofauna structure of the Guadiana estuary and adjacent coastal area (SE Portugal/SW Spain): Before and after Alqueva dam construction. Coast. Shelf. Sci. 70(1-2), 39-51.

Chícharo, L., Hamadou, R., Amaral, A., Range, P., Mateus, C., Piló, D., Marques, R., Morais,P., Chícharo, M. 2009. Application and demonstration of the ecohydrology approach for the sustainable functioning of the Guadiana estuary (South Portugal). Ecohydrol. Hydrobiol. 9(1), 55-71.

Chícharo, L., Ben-Hamadou, R., Amaral, A., Range, P., Mateus, C., Piló, D., Marques, R., Morais, P., Chícharo, M.A. 2010. International Centre for Coastal Ecohydrology - Applying the ecohydrology approach for the sustainable functioning of coastal ecosystems. Hydrocomplexity: New Tools for Solving Wicked Water Problems (Conference Paper). Proceedings of the Xth Kovacs Colloquium, 2-3 July 2010, Paris, France. ISBN 978-1-907161-11-7. IAHS-AISH Publication 338, 163-165.

Colosimo, A., Giuliani, A., Maranghia, F., Brix, O., Thorkildsen, S., Fischer, T., Knust, R., Poertner, H.O. 2003. Physiological and genetical adaptation to temperature in fish populations. Cont. Shelf Res. 23, 1919-1928.

Costa, M.J., Vasconcelos, R., Costa, J.L., Cabral, H.N. 2007. River flow influence on the fish community of the Tagus estuary (Portugal). Hydrobiol. 587, 113-123.

Csirke, J., Sharp, G.D. 1984. Proceedings of the Expert consultation to examine the changes in abundance and species composition of neritic fish resources, San Jose, Costa Rica, 18-29 April 1983. FAO Fish. Rep. Ser. 291(1), FAO, Rome, pp. 102.

Cury, P., Bakun, A., Crawford, R.J.M., Jarre, A., Quinones, R.A., Shannon, L.J.H., Verheye, M. 2000. Small pelagic in upwelling systems: patterns of interaction and structural changes in "wasp-waist" ecosystems. ICES J. Mar. Sci. 57, 603-618.

Domingues, P.M., Bettencourt, V., Guerra, A. 2006. Growth of Sepia officinalis in captivity and in nature. Vie et Milieu. Life Env. 56, 109-120.

Erzini, K. 2005. Trends in NE Atlantic landings (southern Portugal): identifying the relative importance of fisheries and environmental variables. Fish. Oceanogr. 14, 195-209.

Erzini, K., Inejih, C.A.O., Stobberup, K.A. 2005. An application of two techniques for the analysis of short, multivariate non-stationary time-series of Mauritanian trawl survey data. ICES J. Mar. Sci. 62, 353-359.

FAO 1995. Effects of riverine inputs on coastal ecosystems and fisheries resources. FAO Fisheries Technical Paper. No.349. FAO, Rome. 133p.

Fréon, P., Cury, P., Shannon, L., Roy, C. 2005. Sustainable exploitation of small pelagic fish stocks challenged by environmental and ecosystem changes: a review. Bull. Mar. Sci. 76, 385-462.

Fröese, R., Pauly, D. 2009. Fishbase. Worldwide Web Electronic Publication, Available at http://www. fishbase.org

Guerra, A. 2006. Ecology of S. officinalis. Vie et Milieu. Life Env. 56, 97-107.

Guisande, C., Cabanas, J.M., Vergara, A.R., Riveiro, I. 2001. Effect of climate on recruitment success of Atlantic Iberian sardine Sardina pilchardus. Mar. Ecol. Progr. Ser. 223, 243-250.

Hare, J., Alexander, M., Fogarty, M., Williams, E., Scott, J. 2010. Forecasting the dynamics of a coastal fishery species using a coupled climate-population model. Ecol. Appl. 20, 452-464.

Houde, E.D. 1987. Fish early life dynamics and recruitment variability. Am. Fish. S. S. 2, 17-29.

Hurrell, J.W. 1995. Decadal trends in the North Atlantic Oscillation: regional temperatures and precipitation. Science 269, 676-679.

IPCC 2001. Climate Change 2001. Synthesis Report. A Contribution of Working Groups I, II, and III to the Third Assessment Report of the Intergovernmental Panel on Climate Change. Cambridge University Press, Cambridge, UK.

Jorge, I., Sobral, M. 2004. Alguns aspectos da biología e ecología da população de choco, S. officinalis da região de Aveiro e do litoral adjacente. [Some aspects of the biology and ecology of the population of cuttlefish, S. officinalis of the Aveiro region and adjacent coast]. Relat. Cient. Téc. IPIMAR, sér. Digit. 15, pp. 29.

Kawasaki, T., Tanaka, S., Toba, Y., Taniguchi, A. 1991. Long-term variability of pelagic fish population and their environmental. Pergamon Press, Tokyo, Japan.

Landaeta, M.F., Castro, L.R. 2002. Spring spawning and early nursery zone of the mesopelagic fish Maurolicus parvipinnis at the coastal upwelling zone off 
Talcahuano, central Chile. Mar. Ecol. Progr. Ser. 226, 179-191.

Lehodey, P., Alheit, J., Barange, M., Baumgartner, T., Beaugrand, G., Drinkwater, K., Fromentin, J-M., Hare, S., Ottersen, G., Perry, R.I., Roy, C., van der Lingen, C.D., Werner, F. 2006. Climate variability, fish and fisheries. J. Climate 19, 5009-5030.

Ligas, A., De Ranieri, S., Micheli, D., Realea, B., Sartora, P., Sbranaa, M., Belcarib, P. 2010. Analysis of the landings and trawl survey time series from the Tyrrhenian Sea (NW Mediterranean). Fish. Res. 105(1), 46-56.

Lluch-Belda, D., Crawford, R.M.J., Kawasaki, T., MacCall, A.D., Parrish, R.H., Schwartzlose, R.A., Smith, P.E. 1989. World-wide fluctuations of sardine and anchovy stocks: The regime problem. S. Afr. J. of Marine Sc. 8,195-205.

Lluch-Cota, D.B., Hernandez-Vazquez, S., Lluch-Cota, S.E. 1997. Empirical investigation on the relationship between climate and small pelagic global regimes and El Nino-Southern Oscillation (ENSO). FAO Fisheries Circular No. 934, FAO, Rome, pp. 48.

Mann, K.H., Lazier, J.R.N. 1991. Dynamics of marine ecosystems: biological physical interactions in the oceans. Blackwell Scientific Publications, Boston, MA.

Morais, P. 2007. The life cycle of Engraulis encrasicolus sensu lato in the Guadiana estuary: ecology, ecohydrology and biology. $\mathrm{PhD}$ thesis, Universidade do Algarve, Portugal, $238 \mathrm{pp}$.

Morais, P., Chícharo, M.A., Chícharo, L. 2009. Changes in a temperate estuary during the filling of the biggest European dam. Sci. Total Env. 407, 2245-2259.

Motos, L., Uriarte, A., Valencia, V. 1996. The spawning environment of the Bay of Biscay anchovy (Engraulis encrasicolus L.). Sci. Mar. 60, 117-140.

Myers, R., Worm, B. 2003. Rapid worldwide depletion of predatory fish communities. Nature 423, 280-283.

Oliveira, P.B., Angelica, M.M., Fernandes, J., Castro, J., Cruz, T. 2008. Near shore oceanographic conditions off SW Portugal in summer 2006 and 2007 from satellite and in situ data. Proceedings of the $2^{\text {nd }}$ MERIS/ (A) ATSR User Workshop, 22-26 September 2008, Frascati, Italy.

Palomera, I., Olivar, M.P., Salat, J., Sabates, A., Coll, M., García, A., Morales-Nin, B. 2007. Small pelagic fish in the NW Mediterranean Sea: Na ecological review. Progr. Oceanogr. 74, 377-396.

Pease, B.C. 1999. A spatially oriented analysis of estuaries and their associated commercial fisheries in New South Wales, Australia. Fish. Res. 42, 67-86.

Ré, P., Farinha, A., Meneses, I. 1983. Anchovy spawning in Portuguese estuaries (Engraulis encrasicolus, Pisces: Engraulidae). Cybium 7(1), 29-38.

Relvas, P., Barton, E.D. 2002.Mesoescale patterns in the Cape São Vicente (Iberian Peninsula) upwelling region. J. Geophys. Res. 107(C10), 28(1-23).

Relvas, P., Barton, E.D., Dubert, J., Oliveira, P.B., Peliz, A., da Silva, J.C.B., Santos, A.M.P. 2007. Physical oceanography of the western Iberia ecosystem: Latest views and challenges. Progr. Oceanogr 74, 149-173.

Roessig, J.M., Woodley, C.M., Cech, J.J., Hansen, L.J. 2004. Effects of global climate change on marine and estuarine fishes and fisheries. Rev. Fish Biol. Fisher. 14, 251-275.

Ruiz, J., García-Isarch, E., Huertas, I.E., Prieto L., Juárez, A., Muñoz J.L., Sánchez-Lamadrid, A., Rodríguez, S., Naranjo, J.M. and Baldó, F. 2006. Meteorological forcing and ocean dynamics controlling Engraulis encrasicolus early life stages and catches in the Gulf of Cádiz. Deep-Sea Res. 53, 1363-1376

Santos, A.M.P., Chícharo, A., Santos, D.A., Miota, T., Oliveira, P.B., Peliz, A., Ré, P. 2007. Physical-biological interactions in the life history of small pelagic fish in the western Iberia upwelling ecosystem. Progr. Oceanogr. 74, 192-209.

Santos, A., Borges, M., Groom, S. 2001. Sardine and horse mackerel recruitment and upwelling off Portugal. ICES J. Mar. Sci. 58, 589-596.

Santos, M.B., González-Quirós, R., Riveiro, I., Cabanas, J.M., Porteiro, C., Pierce, G. J. 2012. Cycles, trends, and residual variation in the Iberian sardine (Sardina pilchardus) recruitment series and their relationship with the environment. ICES J. Mar. Sci. 69, 739-750.

Sobrino, I., Silva, L., Bellido, J.M., Ramos, F. 2002. Rainfall, river discharges and sea temperature as factors affecting abundance of two coastal benthic cephalopod species in the Gulf of Cádiz (SW Spain). Bull. Mar. Sci. 71, 851-865.

Sohel, M.S.I., Ullah, M.H. 2012. Ecohydrology: A framework for overcoming the environmental impacts of shrimp aquaculture on the coastal zone of Bangladesh. Ocean Coast. Manage. 63, 67-78.

Wang, J., Pierce, G.J., Boyle, P.R., Denis, V., Robin, J.-P., Bellido, J.M. 2003. Spatial and temporal patterns of cuttlefish (Sepia officinalis) abundance and environmental influences - a case study using trawl fishery data in French Atlantic coastal, English Channel, and adjacent waters. ICES J. Mar. Sci. 60, 1149-1158.

Wilson, J.R., Broitman, B.R., Caselle, J.E., Wendt, D.E. 2008. Recruitment of coastal fishes and oceanographic variability in central California. Estuar. Coast. Shelf Sci. 79, 483-490.

Wolanski, E., Boorman, L.A., Chícharo, L., Langlois-Saliou, E., Lara, R., Plater, A.J., Uncles, R.J., Zalewski, M. 2004. Ecohydrology as a new tool for sustainable management of estuaries and coastal waters. Wetl. Ecol. Manag. 12, 235-276.

Wolanski, E., Chícharo, L., Chícharo, M.A., Morais, P. 2006. An ecohydrology model of the Guadiana Estuary (South Portugal). Estuar. Coast. Shelf Sci. 70(1-2), 85-97.

Zalewski, M. 1998. Ecohydrology and fisheries management. Ital. J. Zool. 65, 501-506.

Zalewski, M. 2000. Ecohydrology-the scientific background to use ecosystem properties as management tools toward sustainability of water resources. Guest Editorial, Ecol. Eng. 16, 1-8.

Zalewski, M. 2003. Ecohydrology - new conceptual tool for restoration and sustainable use of fisheries resources in rivers. Abstract published in the Second International Symposium on the Management of Large Rivers for Fisheries. Phnom Penh, Mekong River Commission.

Zalewski, M., Janauer, G.A., Jolankai, G. 1997. Ecohydrology. A new paradigm for the sustainable use of 
aquatic resources. UNESCO IHP Technical Document in Hydrology No. 7.; IHP - V Projects 2.3/2.4, UNESCO Paris, pp. 60.

Zhang, H., Sannasiraj, S.A., Chan, E.S. 2009. Wind wave effects on hydrodynamic modeling of ocean circulation in the South China Sea. The Open Civil. Eng. J. 3, 48-61.

Zuur, A.F., Fryer, R.J., Jolliffe, I.T., Dekker, R., Beukema, J.J. 2003a. Estimating common trends in multivariate time series using dynamic factor analysis. Environmetrics 14, 665-685.
Zuur, A.F., Ieno, E.N., Elphick, C.S. 2009. A protocol for data exploration to avoid common statistical problems. Meth. Ecol. Evol. 1, 3-14.

Zuur, A.F., Ieno, E.N., Smith, G.M. 2007. Analyzing Ecological Data. Springer, London.

Zuur, A.F., Pierce, G.J. 2004. Common trends in Northeast Atlantic Squid time series. J. Sea Res. 52, 57-72.

Zuur, A.F., Tuck, I.D., Bailey, N. 2003b. Dynamic factor analysis to estimate common trends in fisheries time series. Can. J. of Fish. Aquat. Sci. 60, 542-552. 